\title{
Circulating levels of sulphasalazine and its metabolites and their relation to the clinical efficacy of the drug in ulcerative colitis
}

\author{
A K AZAD KHAN AND S C TRUELOVE \\ From the Nuffield Department of Clinical Medicine, Radcliffe Infirmary, Oxford
}

SUMMARY One hundred and eighty-five patients with ulcerative colitis have been studied serially while receiving regular maintenance treatment with sulphasalazine (SASP) in a dose of $0.5 \mathrm{~g}$ four times daily. The circulating levels of the drug and its principal metabolites during remission do not influence the liability to relapse. When relapse does occur, the circulating level of sulphapyridine falls and remains depressed until remission occurs. This fall during a relapse is most pronounced when the patient suffers from universal colitis and is least marked in cases of distal colitis.

Das et al. ${ }^{1}$ measured the serum concentration of sulphasalazine (SASP) and its metabolites in different phases of ulcerative colitis and showed that patients in remission had higher concentrations of total-sulphapyridine (total-SP) $(>20 \mu \mathrm{g} / \mathrm{ml})$ than those in relapse or those who failed to achieve remission $(<20 \mu \mathrm{g} / \mathrm{ml})$. From these findings, they concluded that 'the most effective therapeutic concentration of total SP for the achievement of clinical remissions and not associated with sideeffects, lies within a range of 20 to $50 \mu \mathrm{g} / \mathrm{ml}$ of serum'.

The present study was designed to explore, first, whether the circulating concentrations of sulphasalazine and its metabolites in patients with ulcerative colitis during remission influence the liability to relapse, and secondly, what happens to the circulating concentrations in the event of a relapse.

\section{Methods}

\section{PATIENTS}

One hundred and eighty-five patients with ulcerative colitis, all of whom were receiving regular maintenance treatment with SASP in a dose of $0.5 \mathrm{~g}$ four times daily, were studied serially. The disease had been previously diagnosed on the basis of symptoms, sigmoidoscopic appearances, histology of the rectal mucosa, and the radiological appearances. Remission or relapse were defined on the

Received for publication 4 March 1980 basis of the symptoms, the sigmoidoscopic appearances, and the histology of the rectal mucosa as graded by Truelove and Richards. ${ }^{2}$ Some clinical details of the patients are given in Table 1.

The patients were treated during any relapses with oral and rectal prednisolone in addition to the SASP, which was continued in the same dosage during the whole period of the study. Some patients took tablets of diazepam, nitrazepam, iron, or vitamins in addition to the SASP.

Venous blood was collected at the outpatient department between 2 and 4.30p.m. Patients not taking SASP regularly were not included in the study. The blood samples were allowed to clot and the serum was separated. The serum samples were stored at $-25^{\circ} \mathrm{C}$ until final biochemical analysis. The samples were analysed for concentrations of sulphasalazine (SASP), free-sulphapyridine (freeSP), N ${ }^{4}$-acetyl-sulphapyridine (AC-SP), sulphapyridine-O-glucuronide (SP-Gluc), $\mathrm{N}^{4}$-acetyl-sulphapyridine-O-glucuronide (AC-SP-Gluc), total-sulphapyridine (free-sulphapyridine and all its metabolites) (total-SP) and total-5-aminosalicylic acid (free-5aminosalicylic acid-acetyl-5-aminosalicylic acid) (total-5-ASA). ${ }^{3-5}$ The biochemical estimation of the serum concentrations was done without knowledge of the clinical state of the patients.

The patients were followed for a period of one to three years. All the patients were seen repeatedly and hence blood samples were obtained on several occasions, in some patients as many as 12 times. The mean number of collections per patient was five. Table 1 shows some of the clinical details of 
Table 1 Clinical details of 185 patients with ulcerative colitis studied and period over which observations on circulating levels of SASP and its metabolites were made

\begin{tabular}{|c|c|}
\hline & No. of patients \\
\hline \multicolumn{2}{|l|}{ Age $(\mathrm{yr})$} \\
\hline Less than 20 & 9) \\
\hline 20 to 40 & 66 \\
\hline 41 to 60 & $78\}^{185}$ \\
\hline More than 60 & 32 \\
\hline \multicolumn{2}{|l|}{ Sex } \\
\hline Male & 105 \\
\hline Female & $80\}^{185}$ \\
\hline \multicolumn{2}{|l|}{ Extent of involvement } \\
\hline Entire colon (universal colitis) & $44)$ \\
\hline From rectum to beyond splenic flexure & \\
\hline (extensive colitis) & $18>185$ \\
\hline From rectum up to splenic flexure & \\
\hline (distal colitis) & 123 \\
\hline \multicolumn{2}{|l|}{ Period of study (yr) } \\
\hline 1 & $39)$ \\
\hline 1 to 2 & $67>185$ \\
\hline More than 2 & 79 (2) \\
\hline
\end{tabular}

the 185 patients with ulcerative colitis and the length of time over which they were studied. During this period 68 patients relapsed, some of them on more than one occasion. The mean values of the results for all the collections during remission were calculated for each individual patient. In the case of the 68 patients who relapsed at least once during the study, the corresponding mean values for the findings during relapse were calculated and were used to compare remission and relapse.

\section{Results}

There were marked interindividual variations in respect of the serum concentrations of SASP and of SP and its metabolites. By contrast, each individual maintained reasonably constant serum concentrations of total-SP, free-SP, and AC-SP in the serum, so long as his clinical condition remained unchanged and provided that he took SASP regularly. SASP concentrations within an individual were, however, not as stable as SP concentrations. As an example, in one patient these estimations were done at six different times during remissions and the mean values of SASP and total-SP (with their SDs) were $9 \cdot 3 \pm 3 \cdot 2$ (range 5.5 to 13.6$) \mu \mathrm{g} / \mathrm{ml}$ and $32.9 \pm 2.9$ (range 29.1 to 37.8$) \mu \mathrm{g} / \mathrm{ml}$, respectively. Sulphasalazine is absorbed from the small intestine and its half-life is short (five to eight hours). The blood samples were drawn between 2 and $4.30 \mathrm{pm}$ and, although the time that elapsed between the last dose of SASP and the time of collection of blood averaged three hours, it ranged between two and eight hours. There was, however, no correlation between the serum concentration of SASP and the time that elapsed between the last dose and the time of collection of blood. The half-life of SP is longer than that of SASP, being about 10 hours in patients with ulcerative colitis. It is released slowly from SASP. These factors help to maintain a stable serum concentration. The serum concentration of 5-ASA was very low and was usually below $1 \mu \mathrm{g} / \mathrm{ml}$. It was estimated in 120 samples from 50 patients. Further estimation of 5-ASA was then abandoned.

There was no correlation between the serum concentration of SASP and the serum concentration of SP or its metabolites. The acetylator phenotype could be determined in all but four of the patients by estimating total-SP and the percentage of it in the acetylated form (AC-SP + AC-SP-Gluc). In four patients, the acetylator phenotype could not be determined because they had serum total-SP concentrations below $4 \mu \mathrm{g} / \mathrm{ml}$ and the concentrations of different metabolites of SP were proportionately low and hence not considered to be sufficiently reliable for the estimation of acetylator phenotype. In Table 2 are shown the serum concentrations of SASP and of its SP metabolites in fast and slow acetylators.

The acetylator phenotype of a patient did not change in different clinical phases of ulcerative colitis (remission or relapse).

In addition to acetylation, SP also undergoes hydroxylation, the product of which in turn undergoes glucuronidation. The hydroxylation of SP was variable in different subjects and it also varied in the same individual from time to time. The amount of hydroxylated SP (SP-Gluc + AC-SPGluc) was significantly higher in the fast acetylators, sufficiently so to cause the percentage of total hydroxylation to be higher in such subjects. This was mainly because of the significantly higher concentrations of AC-SP-Gluc in the fast acetylators. Perhaps acetylation indirectly enhances hydroxylation. There was no significant difference in the serum concentrations of SASP in the fast and slow

Table 2 Serum concentrations of SASP and its SP metabolites in 181 patients with ulcerative colitis during remission shown separately for fast and slow acetylators

\begin{tabular}{|c|c|c|c|}
\hline & \multicolumn{3}{|c|}{ Serum concentiations in $\mu \mathrm{g} / \mathrm{ml}$ (mean $\pm S D)$} \\
\hline & $\begin{array}{l}\text { Fast } \\
\text { acetylators } \\
(n=69)\end{array}$ & $\begin{array}{l}\text { Slow } \\
\text { acetylators } \\
(n=112)\end{array}$ & $t$ test \\
\hline SASP & $6.9 \pm 5.4$ & $6 \cdot 1-3 \cdot 8$ & $1 \cdot 1 \mathrm{NS}$ \\
\hline Total-SP & $20 \cdot 7 \pm 9 \cdot 6$ & $27 \cdot 0-10 \cdot 2$ & $3.7 \mathrm{P}<0.001$ \\
\hline Free-SP & $7 \cdot 5+4 \cdot 3$ & $18 \cdot 5=8 \cdot 2$ & $9.2 \mathrm{P}<0.0001$ \\
\hline AC-SP & $9 \cdot 7 \div 4 \cdot 3$ & $5 \cdot 7 \therefore 2 \cdot 4$ & $7.1 P<0.0001$ \\
\hline SP-Gluc & $0.4 \pm 0.4$ & $0 \cdot 7+0.8$ & $2.0 \mathrm{P}<0.05$ \\
\hline AC-SP-Gluc & $3 \cdot 5+2 \cdot 0$ & $2 \cdot 3 \pm 1 \cdot 6$ & $4.1 \mathrm{P}<0.001$ \\
\hline$\%$ Acetylation & $63 \cdot 8 \pm 8 \cdot 6$ & $29 \cdot 7=7 \cdot 3$ & $25.5 \mathrm{P}<0.00001$ \\
\hline$\%$ Hydroxylation & $20 \cdot 2 \pm 9 \cdot 9$ & $11 \cdot 6+9 \cdot 6$ & $5 \cdot 2 \mathrm{P}<0.001$ \\
\hline
\end{tabular}


Table 3 Distribution of patients with serum concentration of total-SP of above $35 \mu \mathrm{g} / \mathrm{ml}$ in fast and slow acetylators

\begin{tabular}{lcccl}
\hline $\begin{array}{l}\text { Acetylator } \\
\text { phenotype }\end{array}$ & $\begin{array}{l}\text { No. of } \\
\text { patients }\end{array}$ & $\begin{array}{l}\text { Patients with total-SP } \\
\text { over } 35 \mu \mathrm{g} / \mathrm{ml} \text { of serum }\end{array}$ & $\begin{array}{l}\text { Significance of } \\
\text { difference }\end{array}$ \\
\cline { 2 - 4 } & & $($ no.) & $(\%)$ & \\
\hline Fast & 69 & 3 & 4.3 & $\begin{array}{l}\chi^{2}=7.03 \\
\mathrm{n}=1 \\
\mathrm{P}<0.01\end{array}$ \\
Slow & 112 & 20 & 17.9 & \\
\end{tabular}

Table 4 Relapse rate in patients with ulcerative colitis in relation to circulating levels of total-SP during remission

\begin{tabular}{lcll}
\hline $\begin{array}{l}\text { Circulating level of } \\
\text { total-SP during } \\
\text { remission }(\mu \mathrm{g} / \mathrm{ml})\end{array}$ & $\begin{array}{l}\text { Number of } \\
\text { patients }\end{array}$ & $\begin{array}{l}\text { Number } \\
\text { relapsing }\end{array}$ & $\begin{array}{l}\text { Percentage } \\
\text { relapsing }\end{array}$ \\
\hline $\begin{array}{l}\text { Low } \\
<12\end{array}$ & 23 & 9 & 39 \\
$\begin{array}{l}\text { Moderate } \\
12-20\end{array}$ & 51 & 13 & 25 \\
$\begin{array}{l}\text { High } \\
>20\end{array}$ & 111 & 46 & 41 \\
\hline
\end{tabular}

acetylators. Fast acetylators had significantly higher serum concentrations of AC-SP and AC-SP-Gluc and significantly lower serum concentration of free-SP and total-SP than the slow acetylators. Out of the 23 patients who had serum total-SP concentration above $35 \mu \mathrm{g} / \mathrm{ml}, 20$ were slow acetylators and only three were fast acetylators, a difference which is highly significant (Table 3 ). Acetylsulphapyridine is more polar than free-SP and hence is excreted faster by the kidneys. The result is that the slow acetylators retain a larger amount of total-SP in their circulation than the fast acetylators.

These data were then analysed to answer the following two questions: (1) when patients are maintained on the same dose of SASP, does the circulating concentration of total-SP during remission influence the liability to relapse?; (2) what happens to the circulating concentrations of SASP and its metabolites when patients with ulcerative colitis relapse?

\section{CIRCULATING TOTAL-SP AND LIABILITY TO RELA PSE}

Table 4 shows the relapse rate in three groups of patients. The first group was composed of patients all of whom during remission had a mean serum concentration of total-SP of less than $12 \mu \mathrm{g} / \mathrm{ml}$, the second of patients with a mean serum concentration of $12-20 \mu \mathrm{g} / \mathrm{ml}$, and the third of patients with a mean serum concentration of more than $20 \mu \mathrm{g} / \mathrm{ml}$. There was no significant difference in the relapse rate in these three groups, demonstrating that, when patients are maintained on the same dose of SASP, the circulating concentration of total-SP during remission does not influence the liability to relapse. In view of these findings, it is not surprising that the relapse rate was virtually identical in the fast and slow acetylaters, being $39 \%$ and $37 \%$ respectively.

The circulating level of SASP likewise does not influence the relapse rate in patients being maintained on a standard dose of the drug.

It is worth mentioning that these three groups of patients were comparable in respect of a number of important features, such as their age and sex composition, the length of history of ulcerative colitis, and the extent of colitis as judged radiologically.

\section{EFFECT OF RELAPSE ON CIRCULATING CONCENTRATIONS}

Table 5 shows that the serum concentration of SASP did not significantly differ between remission and relapse in the same patient. On the other hand,

Table 5 Serum concentration of SASP and its SP metabolites in patients with ulcerative colitis during remission and relapse

\begin{tabular}{|c|c|c|c|c|c|c|c|c|c|}
\hline & \multicolumn{9}{|c|}{ Serum concentration $(\mu \mathrm{g} / \mathrm{ml}$, mean $\pm S D)$} \\
\hline & \multicolumn{3}{|c|}{ Distal UC $(n=41)$} & \multicolumn{3}{|c|}{ Extensive $U C(n=10)$} & \multicolumn{3}{|c|}{ Universal UC $(n=17)$} \\
\hline & Remission & Relapse & $t$ & Remission & Relapse & $t$ & Remission & Relapse & $t$ \\
\hline SASP & $6 \cdot 7 \pm 3 \cdot 1$ & $6 \cdot 3 \pm 3 \cdot 0$ & $\begin{array}{l}t=1 \cdot 0 \\
N S\end{array}$ & $9 \cdot 4 \pm 5 \cdot 2$ & $9 \cdot 9 \pm 7 \cdot 2$ & $\begin{array}{l}t=0.4 \\
\mathrm{NS}\end{array}$ & $5 \cdot 8 \pm 3.9$ & $5 \cdot 7 \pm 4 \cdot 6$ & $\begin{array}{l}t=0 \cdot 2 \\
\text { NS }\end{array}$ \\
\hline Total-SP & $27 \cdot 7 \pm 7 \cdot 8$ & $23 \cdot 1 \pm 7 \cdot 4$ & $\begin{array}{l}t=4.9 \\
P<0.001\end{array}$ & $29 \cdot 0 \pm 7 \cdot 1$ & $19 \cdot 8 \pm 9 \cdot 5$ & $\begin{array}{l}t=3.8 \\
P<0.01\end{array}$ & $22 \cdot 8 \pm 15 \cdot 0$ & $14 \cdot 0 \pm 13 \cdot 4$ & $\begin{array}{l}t=4.7 \\
P<0.001\end{array}$ \\
\hline Free-SP & $17 \cdot 0 \pm 8 \cdot 1$ & $13 \cdot 6 \pm 7 \cdot 0$ & $\begin{array}{l}t=4.0 \\
P<0.001\end{array}$ & $15 \cdot 9 \pm 7 \cdot 6$ & $10 \cdot 6 \pm 7 \cdot 5$ & $\begin{array}{l}t=3.2 \\
P<0.02\end{array}$ & $16 \cdot 2 \pm 12 \cdot 7$ & $9 \cdot 7 \pm 10 \cdot 5$ & $\begin{array}{l}t=3.0 \\
P<0.01\end{array}$ \\
\hline Ac-SP & $8 \cdot 2 \pm 3 \cdot 6$ & $7 \cdot 2 \pm 3 \cdot 7$ & $\begin{array}{l}t=3.8 \\
P<0.001\end{array}$ & $9 \cdot 4 \pm 4 \cdot 4$ & $6 \cdot 9 \pm 4 \cdot 1$ & $\begin{array}{l}t=2.5 \\
P<0.05\end{array}$ & $8 \cdot 2 \pm 3 \cdot 5$ & $5 \cdot 7 \pm 3 \cdot 7$ & $\begin{array}{l}t=4.6 \\
P<0.001\end{array}$ \\
\hline SP-Gluc & $0.6 \pm 0.6$ & $0 \cdot 2 \pm 0 \cdot 2$ & $\begin{array}{l}t=3.3 \\
P<0.01\end{array}$ & $0.3 \pm 0.4$ & $0 \cdot 3 \pm 0 \cdot 2$ & $\begin{array}{l}t=0 \cdot 2 \\
\text { NS }\end{array}$ & $0.6 \pm 0.7$ & $0.4 \pm 0.5$ & $\begin{array}{l}t=1.4 \\
\text { NS }\end{array}$ \\
\hline Ac-SP-Gluc & $2.9 \pm 1.6$ & $2 \cdot 2 \pm 1 \cdot 6$ & $\begin{array}{l}t=2.2 \\
P<0.05\end{array}$ & $3 \cdot 5 \pm 2 \cdot 0$ & $2 \cdot 6 \pm 1 \cdot 7$ & $\begin{array}{l}t=1.4 \\
\text { NS }\end{array}$ & $2 \cdot 5 \pm 2 \cdot 4$ & $2 \cdot 1 \pm 2 \cdot 3$ & $\begin{array}{l}t=2.7 \\
P<0.02\end{array}$ \\
\hline
\end{tabular}




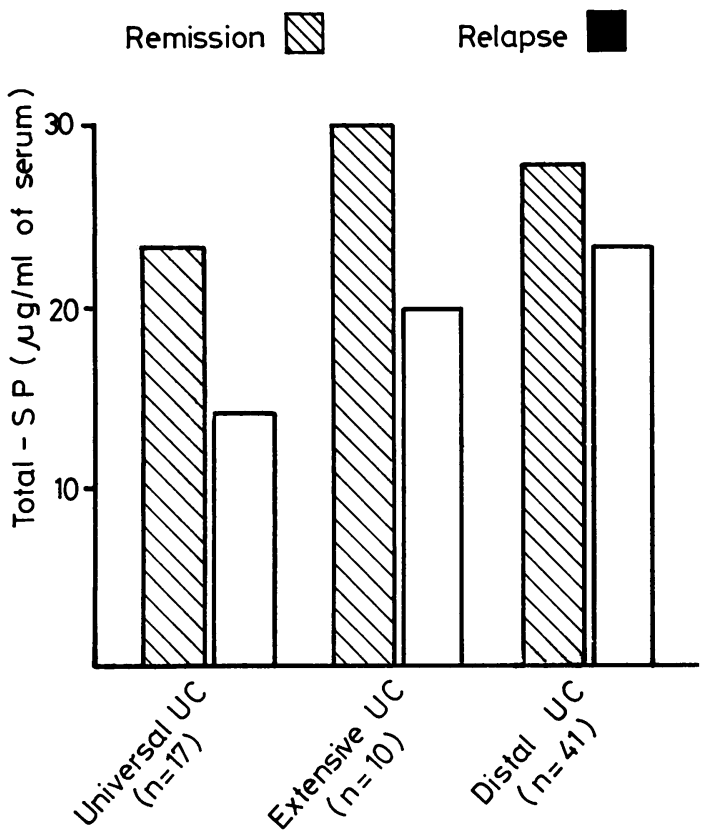

Fig. 1 Mean serum concentration of total-SP during remission and relapse in patients with ulcerative colitis of varying grades of extent.

serum concentrations of total-SP and of its two principal components-namely, free-SP and ACSP-fell sharply during relapse. The greater the extent of the disease, the more marked was the fall. In Fig. 1 is shown the mean serum concentration of total-SP during remissions and relapses in patients with ulcerative colitis of varying grades of extent. During relapse the mean fall in the groups of patients with distal, extensive, and universal colitis were $16 \cdot 6,31 \cdot 7$, and $38.6 \%$ respectively. The two minor metabolites of SP-namely, SP-Gluc and AC-SP-Gluc-showed the same trend but sometimes the drop failed to attain statistical significance presumably because of the lower serum concentrations and the high standard deviations. However, if the patients with distal, extensive, or universal colitis are taken together, both the SP-Gluc and the AC-SP-Gluc serum concentrations were signifcantly lower during relapse $(\mathrm{P}<0.01)$.

Several of these patients relapsed more than once during the course of the study and in them the serum concentrations of SP and of its metabolites fell during each relapse, coming back towards the original level with remission and falling again when a further relapse occurred. Figure 2, which shows the serum concentrations of the total-SP in one such patient, illustrates this point.

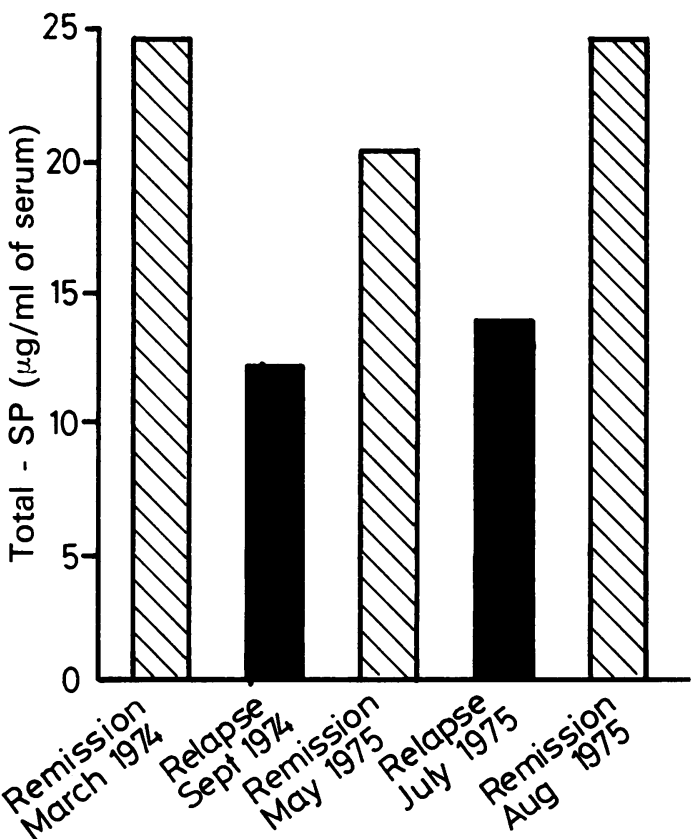

Fig. 2 Serum concentration of total-SP during remission and relapse in one patient.

Nine of the patients with ulcerative colitis from the present study were subjected to panproctocolectomy because of failure to control their disease by medical treatment. Seven out of these nine had universal colitis and the other two had distal colitis. The seven patients with universal colitis had a mean serum total-SP concentration of 22.4 $\mu \mathrm{g} / \mathrm{ml}$ during remission, while the mean level dropped below $7.5 \mu \mathrm{g} / \mathrm{ml}$ during relapse. These patients then failed to improve clinically in spite of vigorous medical treatment and their serum SP concentration also failed to rise, though they continued on SASP in the same dosage as during remission. The colonic specimen removed at panproctocolectomy confirmed the presence of severe ulcerative colitis involving the whole of the colon. The other two patients with distal ulcerative colitis showed only a slight fall in the serum concentration of total-SP (during remission $28.8 \mu \mathrm{g} / \mathrm{ml}$ and during relapse $25.4 \mu \mathrm{g} / \mathrm{ml}$ ) and the resected specimen confirmed that the disease extended only up to the splenic flexure.

\section{Discussion}

The serum concentrations of SP and its metabolites, and of 5-ASA, observed in the present study are comparable with those found by Das et al..$^{1}$ in patients with ulcerative colitis receiving the same 
dose of SASP. It has been confirmed that there is marked interindividual variations in the serum concentrations of SASP and SP. Studies by Schröder and Campbell ${ }^{6}$ and by ourselves ${ }^{7}$ suggest that this is due to differences in absorption by different individuals. The present study shows that, in the steady state, an individual maintains a reasonably constant serum concentration of SP. This is partly because SP is slowly released in the colon by the action of colonic bacteria on SASP, thus maintaining a steady supply. The serum concentration of SASP showed wider variations within the same individual. This could be due to its short half-life and the site of absorption being the small intestine. However, the serum concentration of SASP did not show any correlation with the time that elapsed between the hour of the last dose and the hour of collection of blood, which can be attributed to the existence of an enterohepatic circulation. ${ }^{7}$

The acetylator phenotype could be determined in the patients who had adequate serum concentrations of SP, which applied to virtually all of them. Among the patients with ulcerative colitis there were $38.1 \%$ fast acetylators and $61.9 \%$ slow acetylators. Evans ${ }^{8}$ found the percentage of slow acetylators to be $62 \cdot 2 \%$ among 135 white British subjects, figures which are remarkably similar.

Slow acetylators had higher serum concentrations of total-SP than fast acetylators. Das et al. ${ }^{1}$ obtained similar results. Acetyl-sulphapyridine is more polar than free-SP and hence it is excreted faster by the kidneys. ${ }^{5}{ }^{9}$ Slow acetylators thus have a limited capacity to excrete SP.

Hydroxylation was unimodally distributed in this group of patients with ulcerative colitis and it ranged from 1 to $75 \%$. The percentage of hydroxylation was higher in the fast acetylators than in the slow acetylators. This was mainly because of the higher serum concentration of AC-SP-Gluc in the former. It is probable that acetylated SP is hydroxylated more readily than free-SP.

The apparent discrepancy between the conclusions reached by Das et al. ${ }^{1}$ and those of the present study needs further discussion. Das et al. found that patients with ulcerative colitis during remission had higher concentrations of total-SP than those studied during relapse. In the latter group, "coincidental with clinical improvement following an increase in the dose (of SASP), the serum total-SP concentration rose to within the range of patients responding earlier'. But this can be interpreted in at least two ways: (1) the low serum concentration of total-SP during remission made these patients liable to relapse; (2) the low serum SP concentration during relapse is an effect of the relapse.

The authors recognised both these possibilities but unfortunately chose the first one and, as a result, they advocated a dose of $3 \mathrm{~g}$ daily for regular maintenance therapy. The present study shows that the liability to relapse is not governed by the circulating levels during remission of SASP or of SP and its metabolites. This study also shows that, during relapse, the circulating concentrations of SP and its metabolites drop to lower levels, an observation which could explain the findings of Das et al. ${ }^{1}$ In fact, in their study they had seven patients whose serum concentration of total-SP was above $20 \mu \mathrm{g} / \mathrm{ml}$, which they thought was the therapeutically effective serum concentration, but these patients were still in a relapse state. The fact that during relapse the serum concentration of SP and its metabolites drops to a lower level than during remission can be explained in at least two ways: (1) during relapse there is intestinal hurry and hence there is no time to split SASP adequately or to absorb SP efficiently, or both; (2) inflamed colon may not be efficient in absorbing SP.

During the present study, the patients observed no side-effects from the drug. This was partly because they had all been on SASP for some time before being included in the study and patients not able to tolerate $2 \mathrm{~g}$ SASP daily were not considered for the study.

\section{References}

${ }^{1}$ Das KM, Eastwood MA, McManus JPA, Sircus W. The metabolism of salicylazosulphapyridine in ulcerative colitis. I. The relationship between metabolites and the response to treatment in inpatients. II. The relationship between metabolites and the progress of the disease studied in outpatients. Gut 1973; 14: 631-41.

${ }^{2}$ Truelove SC, Richards WCD. Biopsy studies in ulcerative colitis. $\mathrm{Br}$ Med J 1956; 1: 1315-8.

${ }^{3}$ Hansson KA. Determination of free and acetylated 5-aminosalicylic acid in serum and urine after administration of salicylazosulphapyridine. Acta Pharm Suec 1973; 10: 153-5.

${ }^{4}$ Hansson KA and Sandberg M. Determination of sulphapyridine and its metabolites in biological materials after administration of salicylazosulphapyridine. Acta Pharm Suec 1973; 10: 87-92.

${ }^{5}$ Sandberg $M$ and Hansson KA. Determination of salicylazosulphapyridine in biological materials. Acta Pharm Suec 1973; 10: 107-10.

${ }^{6}$ Schröder $\mathrm{H}$ and Campbell DES. Absorption, metabolism and excretion of salicylazosulfapyridine in man. Clin Pharmacol Ther 1972; 13: 539-51.

${ }^{7}$ Azad Khan AK, Aronson JK and Truelove SC. The disposition and metabolism of sulphasalazine in man. (Submitted for publication).

${ }^{8}$ Evans DAP. An improved and simplified method of detecting the acetylator phenotype. J Med Genet 1969; 6: 405-7.

${ }^{9}$ Dost FH. Grundlagen der Pharmakokinetik, 2nd ed. Stuttgart: George Thieme, 1968: 298-312. 